\title{
Assessment of Use of Diversification Strategy in Enhancing Competitive Performance at Equity Bank, Kenya
}

\author{
Mary Njeri Mwara, Barrack Okello \\ Department of Commerce and Economic Studies, Jomo Kenyatta University of Agriculture and Technology, Juja, Kenya
}

Email Address:

marymwara1@gmail.com (M. N. Mwara),obrackz@gmail.com (B. Okello)

\section{To cite this article:}

Mary Njeri Mwara, Barrack Okello. Assessment of Use of Diversification Strategy in Enhancing Competitive Performance at Equity Bank, Kenya. International Journal of Finance and Banking Research. Vol. 2, No. 2, 2016, pp. 40-48. doi: 10.11648/j.ijfbr.20160202.12

Received: April 8, 2016; Accepted: April 18, 2016; Published: April 28, 2016

\begin{abstract}
Banks and other financial institutions operate in a dynamic environment where opportunities and challenges arise in equal measure. A critical factor that presents challenges and opportunities for the banks and other financial institutions is competition. To beat competitors in the dynamic market and stay abreast with the ever changing market demands, it is imperative for banks to rethink, rework and adjust their diversification strategies appropriately in order to remain relevant in the market. A diversification strategy helps organizations to spread portfolio risks by combining a variety of investments. In fact, organizations that seeks to survive various business cycles or to stay ahead of competition look for ways to diversify and in return, grow, survive and perform well in the long term. This study sought to assess the use of diversification strategy in enhancing competitive performance at Equity Bank Kenya. The study was based on; Technology Acceptance Model, Diversification Strategy Model and the Systems Theory. To achieve the objective of the study, the researcher sought to establish how banccasurance, electronic money transfer and agency banking affects competitive performance of the bank. The researcher used a survey and a descriptive study design. The population of the study included branch managers, corporate managers and divisional managers in charge of Banccassurance, electronic money transfers and Agency banking at Equity Bank while the study sample was selected from the said population by a simple random sampling technique. Data was collected using structured questionnaires that were administered through drop and pick technique. The collected data was analyzed using SPSS version 20. A linear regression analysis was conducted to guide inferences based on diversification strategies in relation to competitive performance of Equity Bank Kenya. The results were presented using the tables appropriately. The results of the study implied that the first null hypothesis was not rejected the second null hypothesis was not rejected, the third null hypothesis was not rejected. The study findings further indicated that the competitive performance of equity bank was not significantly influenced by 0.342 bancassurance, -0.317 electronic money transfers, -0.080 agency banking. However, the study findings indicated that the diversification strategies jointly influenced the competitive performance of Equity Bank $(\mathrm{t}=-3.922 ; \mathrm{p}<0.05)$. It was therefore recommended that bank should innovate its bancassurance products and electronic money transfer systems, motivate employees better and use appropriate technologies that the clientele find to be useful and easy to use.
\end{abstract}

Keywords: Diversification strategy, competitive performance, bancassurance, agency banking, electronic money transfer

\section{Introduction}

\subsection{Background of the Study}

Organizations use diversification strategy whenever they want to grow their business, utilize economies of scale or increase their revenues. Diversification strategy has been defined as a strategy that enables an organization to get into a business that is not related to its current business and which enables it to produce new products for new and existing markets. Ansoff (2003) simplifies this as a strategy that enables an organization to launch new products in existing markets or existing products in new markets. The concept of diversification has been brought about by globalization, liberalization, and intense competition in the corporate sector. A diversification strategy helps an organization to spread risk among various businesses by combining a variety of investments (Mohindru \& Chander, 2010). Technological 
advancements, new entrants and the evolution of banking innovations have seen changes in ways in which consumer's access and demand various products and services and how organizations operate.

Organizations that seek to survive various business cycles or to stay ahead of competition look for ways to diversify. According to Price Waterhouse Coopers (2015) the banking sector in Kenya has witnessed significant growth in deposits, assets, products offering and profitability over the last few years. The players in this sector have experienced increased competitive rivalry as a result of new entrants and technological advancements. With such competition banks have been forced to employ diversification strategies in order to survive in the industry. Banccasurance, Agency banking, Diaspora banking, Digital banking, Borderless banking, Electronic money transfers among others are some of the ways banks in Kenya have diversified their products to enhance their competitive performance. According to Fauzi, Svensson \& Rahman (2010) competitive performance is evident an organization's achievement as reflected in its superior profitability relative to the industry's benchmark. Irrespective of the diversification strategy a bank adopts, when the diversification enhances competitive performance, shareholders and other stakeholders are perceived to be the major beneficiaries of the competitiveness brought about by the diversification strategies.

Diversification has been one of the most important growth strategies applied by organizations and debates in regards to how it affects performance have raged on since the 1950s (Deonanan, 2011). Oyewobi, Windapo \& Cattell (2013) note that the inconsistencies in the impact of diversification on competitive performance depend on different types of diversifications adopted. Research however has been focusing on the diversification-performance relationship in order to determine how it affects the organization. According to Mukherji (1998) firms that diversify and in particular those that engage in related diversification performed better than the others. Different researchers have either found a positive relationship between diversification and competitive performance or have concluded a negative or no relationship between the two. A research conducted by Teimet, et al (2011) among United States of America (USA) banks, diversification was seen to increase the revenue income and reduce volatility of incomes. On the downside, diversification worsened risk-return trade-off. The diversification-performance relationship tends to follow a Ushape (upside-down) implying that although diversification is beneficial, too much of it results in poor performance.

The banking industry in Kenya is governed by the Central Bank of Kenya (CBK), the Companies Act and the Banking Act. Commercial banks in Kenya underwent changes after reforms were made on the financial sector in the early 1990s. There are forty six banking and non-banking institutions and one hundred and nine foreign exchange bureaus in Kenya. The banks, under the Kenya Bankers Association have come together to lobby for the banking industry interests. Banks in Kenya have not been left behind in the quest to stay ahead of competition and Equity bank has been a pacesetter in the industry (Equity Bank Limited, 2015).

Equity bank limited was registered in 1984 and evolved from a small building society, microfinance, and now an allinclusive financial service provider. Equity bank is one of the leading financial institutions in the region with nearly eight million accounts. The bank started out with the strategy of banking the unbanked and the poorly banked population in Kenya. This strategy saw its success in Kenya and this led it to open other branches in Uganda, South Sudan, Rwanda and Tanzania. Equity Bank has been on the forefront of diversification among all the banks in Kenya. Over the last few years it has launched numerous products and services as a way of diversifying its businesses. Some of the products include electronic money transfer (Equitel), banccasurance (Equity Insurance Agency) and agency banking. Diversification strategy has enabled Equity Bank to not only compete with banks but also with insurance and telecommunication industries (Equity Bank Limited, 2015). Local mobile money transfer services like M-Pesa and Airtel have brought in a lot of competition for banks and it has come to a point where banks need to shape up or shape out. These transfer services offer a lot of convenience to the customer in terms of offering a one stop shop as well as a cheap way to transfer money. According to recent data from the Central Bank, there are 22 banks in Kenya that do not meet the minimum capital proposed by the treasury secretary and which might be forced to close soon. These are just but few of the challenges the Kenyan banks are experiencing and the need to adapt to the customer's requirements and diversification is one of the ways that they will be able to do that.

\subsection{Statement of the Problem}

In hyper competitive markets, competition is high and only firms able to build strategies for instance diversification strategies survive. Diversification presents an organization with numerous advantages like spreading investment risk in various businesses, increased profits, and avails economies of scale among others. The failure of banks to embrace diversification has led to poor performance which has affected the various shareholders, indirect dependants and the national economy as a whole. Past studies have shown that advances in technology, changing economic conditions and new entrants in the banking industry have completely revolutionalised the way banks operate. With these new developments, the intensity of competitive rivalry has also increased significantly. Since 1986, Kenya has experienced banking problems which has led to the failure of 37 banks as at 1998 following the crises of 1986-1989, 1993/1994 and 1998. In the year 2002 pre-tax profit declined by 4.5 percent as a result of the stiff competition experienced in the country. The financial sector is one of the most important sectors in the economy and if it fails Kenya will not meet its vision 2030 neither will it fulfill its sustainable development goals. Therefore, it is of utmost importance that studies in regards to diversification and how it affects performance be 
conducted. As the banking industry expands over the years it has been of necessity to research on diversification strategies like banccasurance, electronic money transfer and agency banking. These strategies offer numerous benefits to the organization in terms of increased business, economies of scales and business growth among others. This study sought to focus on how these diversification strategies affect the competitive performance of Equity Bank in Kenya which has seen significant growth over the last few years making it the most profitable bank.

\subsection{Objectives of the Study}

i. To assess the effect of bancassurance on competitive performance of Equity bank Kenya

ii. To determine how electronic money transfer affects competitive performance at Equity bank Kenya

iii. To establish the effect of agency banking on competitive performance at Equity bank Kenya

\subsection{Research Hypotheses}

Ho1: Banccasurance has no significant effect the competitive performance of Equity Bank Kenya

Ho2: Electronic money transfer has no significant effect on competitive performance of Equity Bank Kenya

Ho3: Agency banking has not significant effect on competitive performance of Equity Bank Kenya

\subsection{Justification of the Study}

The researcher chose Equity bank owing to its frontline position in innovating products that meet and exceed customer expectations. Equity bank also has the highest number of customers and being an early adopter of innovations, the researcher found it fit to use the bank as a case. In addition, Equity bank is the first Kenyan bank to obtain a license to venture into telecommunications industry. This is evident in its recently launched Equitel sim-card. The study was expected to increase the knowledge of diversification strategies that enable commercial banks to compete effectively in the industry. Given the various advancements in technology and new entrants among commercial banks, the intensity of competition has increased. Therefore the need to develop organizations that can diversify as a way to improve their competitive capability in the industry was inevitable. A significant number of commercial banks have failed to understand and apply these diversification strategies hence record lower profits as compared to other organizations. By utilizing this diversification strategies banks will be able to make use of opportunities in other sectors like the insurance sector and telecommunication industry.

\subsection{Scope of the Study}

This study was conducted among the corporate managers who are involved in strategy implementation, divisional managers in charge of banccassurance and agency banking as well as the branch managers of Equity Bank Kenya. The aforementioned managers were hypothesized to be the most conversant with organizations diversification strategies. The study was guided by four variables: Banccasurance, electronic money transfer, agency banking and competitive performance. The former three are the independent variables while the latter is the dependent variable. The study was conducted between the months of January and March 2016. The proposed budget for the research was Kenya Shillings 120,000 .

\section{Literature Review}

\subsection{Theoretical Review}

Various models have been formulated to explain the pertinent issues influencing competitive performance in organizations. This study was based on technology acceptance model, diversification model in the context of Ansoff matrix and systems theory.

\subsubsection{Technology Acceptance Model (TAM)}

Davis (1989) developed the Technology Acceptance Model (TAM) from the earlier works that coined the Theory of Reasoned Action (TRA). In his approach, Davis (1989) adapted the Theory of Reasoned Action model to the context of user acceptance of the information system in order to develop the Technology Acceptance Model (TAM). In his work, he opines about two distinct beliefs namely perceived usefulness and perceived ease of use. These two beliefs had previously been identified as being sufficiently enough to predict the attitude of a user toward use of a system (Chuttur, 2009). Davis (1989) model suggested that when users are presented with a new technology, a number of factors influence their decision regarding how and when they will use the new technology. With regards to diversification strategies implemented at Equity bank, the diversification strategy adopted depends on perceived usefulness and perceived ease of use of technologies employed in diversification. As Davis (1989) avers, perceived usefulness is the degree to which Equity Bank employees believe using a particular diversification strategy would enhance his or her job performance. On the other hand, perceived ease of use refers to the degree to which Equity Bank employees believe that using a particular diversification strategy based on innovation would be free of tedious physical and mental effort. This theory finds application in this study as it explains how managers perceive the relevance of the diversification strategies to their jobs and the organizational long-term objectives. The managers therefore embrace the innovative technologies in its diversification strategy once they accept such technologies based on their perceptions of how useful the technologies are to them and the entire organization.

\subsubsection{Diversification Strategy Model}

Diversification is a marketing strategy that was developed in 1957 and is part of the Igor Ansoff's product matrix as one of the four growth strategies. Market penetration is where the 
company markets its existing products in its current market, product development where the company develops a new product in its existing market and market development where the company sells its existing products in a new market. Diversification is the last of the four marketing strategies and also the one with the most risk because it involves a company entering into a new market whilst creating a new product. Diversification strategy can be pursued to enhance a firm's growth when the other three strategies fail to produce desired objectives (Hussain, et al. 2013). It is important to differentiate between diversification strategies and types of diversification. The former could include licensing of new technologies, firm acquisition, developing new products internally, and forming alliances. According to Pearce, Robinson \& Mital, (2008) a company can decide to pursue one of four types of diversification namely, vertical diversification, horizontal diversification, concentric diversification and conglomerate diversification. In relation to the current study, banccasurance, electronic money transfer and agency banking apply concentric diversification which implies new products that make use of existing technologies and marketing system which enlarge the production portfolio of the firm.

\subsubsection{Systems Theory}

Systems theory was brought forward by Ludwig von Bertalanffy in the 1940's. Later Aristotle emphasized that knowledge would only be gotten from understanding the whole part and not derived from single parts. He looked at nature, organization and society as a whole and not as single parts. Systems theory therefore refers to a theory that can be used to investigate every system in nature from a holistic point of view (Mele, Pels \& Polese, 2010). Ludwig von Bertalanffy noted that real systems interact and are open to learning from the environment as well as acquiring positive properties from the organization. Instead of looking at elements as properties of its parts, the systems theory focuses on holism (Chen \& Stroup 1993). For the performance of an organization to be determined, various areas that make up the whole organization for instance the different departments and sources of avenue need to be looked at. This is because the performance is dependent on all those departments and not just one area. In this study for example diversification strategies: bancassurance, electronic money transfers and agency banking need to be looked at against the competitive performance.

\subsection{Empirical Review}

\subsubsection{The Concept of Banccasurance}

Banccasurance was started in Europe in 1980s and spread rapidly to the rest of the world. Banccasurance as a term originates from two words Banque which is a French word meaning 'bank' and Assurance meaning 'insurance'. Banccasurance basically means to sell banking and insurance services in the same organization and more specifically a bank. Sorina, (2012) defines banccasurance as a strategy adopted by insurance companies or banks that enables them to operate the financial market in an integrated manner. The above definitions are synonymous with the fact that bancassurance involves the sale of insurance products in a banking hall. According to Brophy, (2012) the term 'banccasurance was first discovered in Europe where it was linked to the growth of mortgage and consumer credit as well as the liberalization of financial markets. The first bank to venture into banccasurance was Barclays bank in 1965 when it launched Barclays Life.

In Europe, technological advancements and hardening competition among banks have created a conducive environment for the development of banccasurance. Banccasurance has been an important strategy for European banks that look to increase the size of their business, increase their economies of scale, to improve the concept of universal banking as well as competing effectively within the financial industry (Brophy, 2012). Europe has been a pacesetter in bancassurance market penetration. According to a report by Detail Commercial Solicitors (2008) Nigeria has the largest market for insurance products in Africa which provides an opportunity for banks looking to venture into bancassurance. The convenience of a 'one stop shop' has promoted bancassurance making banks the preferred option for customers who need financial services. Actuarists predict numerous benefits to the insurance sector and more so the banking sector in Nigeria as a result of the synergy between insurance companies and banks.

In Kenya the Central Bank has introduced bancassurance policies as a way to monitor the recent spread in the Kenyan banks. Banks are tapping into the insurance market as a way to diversify their products to be able to keep up with the hardening competition. Equity bank has been on the forefront to tap into the markets potential by diversifying into bancassurance. Equity Insurance Agency Limited which is the bancassurance arm of the bank was licensed in May 2007 after it was incorporated in December 2006. It offers both life and non-life products through partnerships with various insurance companies and is a fully owned by Equity Bank (Equity Insurance Agency, 2014). Barclays Bank, National Bank and Kenya Commercial Bank have also ventured into bancassurance over the last few years.

Peng, Jeng \& Wang (2015) conducted a study on how bancassurance affects the efficiency and profitability of banks in Taiwan. They used data provided by banks between 2004 and 2012 and the results showed an increase in commission income, non-interest income and shareholders' value. Banks are therefore advised to employ a diversification strategy rather than a concentration strategy because it promotes better financial performance. A study by Arora \& Jain (2013) set to analyze the influence of bancassurance on the Bank of India and the motivation behind adoption of bancassurance by banks. The study found that the need to keep up with the hardening competition has been the major motivation behind bancassurance. Bancassurance has also been seen to affect the banks performance in a positive way as it has enhanced the growth of banks. The total incomes, net profit, return on investment, 
earnings per share, and capital adequacy ratio indicated higher performance. In Kenya, a study by Waweru (2013) on the effect of bancassurance on the financial performance of commercial banks reveals that banks experience better financial performance as a result of bancassurance. The annual interest on loan advances also increased as a result of bancassurance.

Peng, et al. (2015) addressed the efficiency and profitability of banks as a result of employing a bancassurance strategy. The study noted that the bank experienced benefits of gaining faith by the customers', employees of the bank gained technical knowhow, and increased profitability by the bank. There's need to conduct similar studies in a local setting to identify whether bancassurance as a diversification strategy leads to better competitive performance. The study by Waweru (2013) focused only on the effect of bancassurance on financial performance. He did not consider non-traditional aspects of performance like learning and growth, business and customer There's therefore need to study how diversification strategy affects other aspects of competitive performance like unmatched customer satisfaction, learning and growth as well as its effect on the business perspective which are all critical to success of an organization.

\subsubsection{Electronic Money Transfer}

Over the last years, the world has been moving the technology direction which has had numerous effects on the global economy. New innovations have been coming up day after day and mobile technology is just one of the many innovations which have been developing faster than any other technology in history. Electronic money transfer involves the use of electronic and telecommunication networks to deliver a wide range of value added products to bank customers. According to Ogare (2013) Electronic money transfer involve IT based services such as Automated Teller Machines (ATMs), Smart Cards, Credit cards, Debit Cards, Anytime-Anywhere banking as well as phone banking services. It entails the use of information technology in banking operations. It includes mobile money transfers, interbank transfers, intra-bank transfers using electronic gadgets such as mobile phones, internet, debit cards and credit cards (Steven, 2002). These electronic money transfers improve the quality of customer service, increase customer satisfaction and further enhance customers-banker relationships. As a matter of fact, the use of efficiently programmed electronic money transfer services raises the customer trust and hence earns the bank more repute. A study done by Ogare (2013) affirms that electronic money transfers are critical for delivering customer satisfaction by guaranteeing accuracy of electronic transactions.

As part of the electronic money transfers, mobile money started in the Philippines in 2000 with the introduction of Smart Money which was an electronic cash card connected to a mobile phone by a mobile operator and which was the first of its kind in the world (Dharmapalan, et al., 2014). The quest to compete effectively in the financial industry has seen banks take advantage of mobile money transfer services as a convenient and cheap way to transfer money. Mobile money having started in a $3^{\text {rd }}$ world country Philippines, majority of the developing countries has adopted it because most people are unbanked while a big number of them own mobile phones. According to a report by USAID, (2011) Kenya is the global leader of Mobile Money with the launch of Safaricom's M-pesa in March 2007. The success of M-Pesa gave birth to several partnerships with banks, which include M-shwari and M-Kesho.

Equity Bank has been on the forefront of innovations and a market leader in the Kenyan banking industry with a customer base of over 8 million. The bank obtained a license from the Communications Authority of Kenya (CAK) in 2014 to get into the communications industry and this move facilitated the launch of Equitel. Equitel is a thin sim card that provides a platform for Equity bank customers to access various banking services through their mobile phones. Numerous studies have been done on electronic payment systems. In a study conducted by Jahanshahi, Rezaei, Nawaser, Rajbar and Pitarmber (2011) on the effect of electronic commerce on competitive performance, the result revealed that the system has significant and positive impact on organizational and operational performance of banks. Teoh (2013) discussed the factors that affect the consumer's perception of electronic money transfer services in Malaysia. The study indicated that electronic payment systems have spread not only in Malaysia but in other countries as well. The results of the study reflect that perceived benefits, selfefficacy and ease of use were the main factors.

According to Simon \& Victor (1994) in their research of customer's risk perception of electronic systems, noted that risk is a major determinant of whether customers adopt an electronic system. Issahaku (2012) researched the challenges that affect e-ZWICH, a payment system in Ghana. The level of adoption was low and the study showed that this was due to the frequent machine breakdown, slow service delivery as well as inaccessibility of service on the weekends. He suggests that banks should hold training workshops to make the services aware to the customers as well as investing in quality machinery.

In Kenya a study was conducted by Ngereza \& Iravo (2013) on the challenges influencing the implementation of electronic payment system in Kenya Airways' procurement department. The research identified that, poor security, financial issues, infrastructure, legal and political issues affected the implementation of EPS. The major problem identified was that there was no proper training done for the employees. He suggested that training should be done among the employees so that they are able to use the system more efficiently.

\subsubsection{Agency Banking}

Agent banking is a strategy used by commercial banks to deliver financial services outside the conventional bank branches using non-bank retail outlets relying on point of sale technologies and mobile phones for real time transaction 
processing. Agency banking system is based on a model that enhances access to financial services by allowing small businesses to operate satellite branches of the bank. Agency banking is considered an important strategy that enhances financial inclusiveness in developing countries and especially in rural areas where reaching for poor clients can be expensive due to the fact that transaction numbers and volumes may not cover the cost of operating a bank branch.

In Brazil, agency banking strategy has led to substantial growth of bank agents to the tune of 100,000 outlets reaching out to 13 million unbanked people (Musau, 2010). In addition, out of the 1.53 billion bank transactions done in Brazil, $78 \%$ of the transactions are attributed to agency banking while in Russia, 1.2 billion transactions worth US\$ 4.7 billion were done by bank agents during the first quarter of the year 2007. This banking system has enabled banking institutions to expand their market share, increase their revenues and profitability while incurring minimum cost on the bank agents as opposed to situations when the banks could be operation more branches in the rural areas on their own.

In Kenya, various commercial banks have adopted agency banking and have thus partnered with several bank agents to take banking services closer to the customers in various parts of the country who could otherwise be constrained from accessing the banks by geographical and time barriers. For example, Equity bank (Equity Mashinani), Post bank (Benki Yangu), Cooperative bank (Coop Kwa Jirani) and Kenya Commercial Bank (KCB Mtaani) have launched forays in the segment. Taking a critical look at Equity Bank, recent data from the Central Bank of Kenya indicates that out of the over 10,000 establishments the regulator has licensed to act as agents of banks, Equity Bank claims to have outsourced its banking operations to 5000 active agents. Agency banking is universally considered a strategy for enhancing financial inclusiveness as it enables the banks to reach out to the unbanked citizens in all parts of the country, rural and urban alike. In addition, as Musau (2010) opines, banks and other institutions offering financial services view agency banking networks as a key competitive strategy to attaining local branch presence at minimum cost possible. According to Mass and Ondiek (2009), banks use their agents to sign up new customers by opening accounts for them, and to conduct customer transactions involving deposits and withdrawal of cash or to receive and make payments.

\subsubsection{Competitive Performance}

Competitive performance is usually affected by different factors within the organization. The organizational behavior and culture of an organization influences the level of competitive performance (Griffin \& Moorhead, 2013). A study was conducted by Choi, et al in 2007 in Hong Kong on the performance of banks and the results showed that banks that offered a wide range of products experience better performance in terms of profitability. These banks were more cost efficient that their counterparts who focused on one product. The study therefore suggests that banks should offer a range of products to their customers in order to keep up with intense competition in the industry. Another study conducted by Garo in 2013 on the factors influencing financial performance of Islamic versus conventional banks in Kenya showed that the size of the bank in terms of their capital base and the number of products they offered was a huge determinant of profitability. A study done by Otieno \& Moronge (2014) on how competitive organizational performance is influenced by product diversification among Kenyan banks. The findings showed that technology, information flow, new markets and innovativeness had effect on financial performance. Innovativeness was found to be a factor with the highest influence since it had the highest significant coefficient. A similar study conducted by Maina (2013) on what affects the performance of commercial banks in Kenya notes that diversification caused major improvements on financial performance.

\subsection{Conceptual Framework}

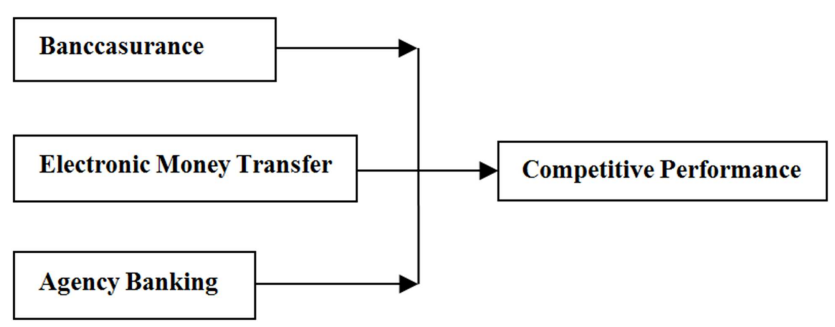

Independent variables Dependent Variable

Figure 1. Conceptual framework.

\subsection{Research Gaps}

The critique of the existing empirical studies has illustrated the fact that a good number of scholars have studied on the different diversification strategies that have been highlighted

in this study. Studies on bancassurance and its effect on performance of banks as well as insurance companies have been extensively researched upon. However, since bank mobile money transfer is a new concept in Kenya, existing literature only focuses on situations where a bank partners with a telecommunication company to provide the service. This partnership entails that the two organizations share the profits derived from the use of this service. However, Equity bank has ventured into the telecommunications industry in order to provide both services under one roof and its effect on the performance of the bank is yet to be researched upon.

More so, studies on the electronic payment systems like electronic money transfer services have not been extensive when it comes to the banking sector. As much as the effect of diversification strategies such as mobile banking and internet banking on performance has been researched upon, other strategies like bancassurance, electronic money transfer and agency banking still lacks sufficient research. It is therefore of utmost important to determine how they affect performance so that financial institutions consider them when diversifying their businesses. 


\section{Methodology}

The study applied a survey strategy and descriptive research design. The target population of this study was 208 managers comprising of branch managers, corporate managers in charge of strategy formulation and divisional mangers in charge of banccasurance and agency banking. A sample of 68 respondents was selected through a simple random sampling procedure. The researcher administered structured questionnaires via a drop and pick method to collect primary data from the sample. The questionnaire items were tested for validity prior to the actual data collection and further the research instrument tested for reliability to guarantee the reliability of the study findings. A Pearson correlation analysis was conducted to determine the relationship between diversification strategies and competitive performance. A In addition, a two tailed significance test was also conducted to test the statistical significance of the relationship. The results of the study were presented using tables.

\section{Research Findings}

\subsection{Correlation Analysis}

The study focused on how diversification strategies influence competitive performance of the bank. The diversification strategies analyzed in this case included bancassurance, electronic money transfer and agency banking. Correlating each of the aforesaid diversification strategies against the competitive performance of the bank enabled the researcher to determine their respective relationships.

\subsubsection{Relationship between Bancassurance and Competitive Performance}

This section outlines the results of correlation analysis between bancassurance and competitive performance (Table 1). The findings are interpreted and further discussed accordingly.

Table 1. Correlation between Bancassurance and Competitive Performance.

\begin{tabular}{lll}
\hline & & Competitive Performance \\
\hline \multirow{3}{*}{ Bancassurance } & Pearson Correlation & .236 \\
& Sig. (2-tailed) & .138 \\
& $\mathrm{~N}$ & 41 \\
\hline
\end{tabular}

**. Correlation is significant at the 0.01 level (2-tailed).

The study revealed that the relationship between bancassurance and competitive performance was positive, weak and not statistically significant $(r=0.236 ; \mathrm{p}>0.01)$. The study observed that the bank operated as an insurance agent and so the revenues collected from bancassurance were shared with the principal insurers and so however much the bank sells insurance products, it does not significantly influence its competitive performance.

\subsubsection{Relationship between Electronic Money Transfer and Competitive Performance}

This section outlines the results of correlation analysis between bancassurance and competitive performance (Table 2). The findings on this section are interpreted and further discussed accordingly.

Table 2. Correlation between Electronic Money Transfer \& Competitive Performance.

\begin{tabular}{lll}
\hline & & Competitive Performance \\
\hline Electronic & Pearson Correlation & -.216 \\
Money & Sig. (2-tailed) & .175 \\
Transfer & $\mathrm{N}$ & 41 \\
\hline
\end{tabular}

**. Correlation is significant at the 0.01 level (2-tailed).

The study also revealed that the relationship between Electronic Money Transfer and competitive performance was negative, weak and statistically insignificant $(r=-0.216 ; \mathrm{p}>$ 0.01). The study observed that the electronic money transfers do not influence the competitive performance of the bank.

\subsubsection{Relationship between Agency Banking and Competitive Performance}

This section outlines the results of correlation analysis between agency banking and competitive performance (Table 3). The findings on this section are interpreted and further discussed accordingly.

Table 3. Correlation between Agency Banking \& Competitive Performance.

\begin{tabular}{lll}
\hline & & Competitive Performance \\
\hline \multirow{2}{*}{ Agency } & Pearson Correlation & -.154 \\
Banking & Sig. (2-tailed) & .336 \\
& $\mathrm{~N}$ & 41 \\
\hline
\end{tabular}

**. Correlation is significant at the 0.01 level (2-tailed).

The study further indicated that the relationship between agency banking and competitive performance was negative, statistically insignificant $(r=-0.154 ; p>0.01)$. However, the study findings indicated that the agency banking system does not impact the performance of the bank.

\subsection{Regression Analysis}

In order to assess the extent to which the diversification strategies adopted related with competitive performance, a multiple regression analysis was conducted.

\subsubsection{Relationship between Diversification Strategies and Competitive Performance}

This study assessed how diversification strategies influenced competitive performance of Equity bank. Table 4, 5 and 6 show the results of multiple regression analysis.

Table 4. Model Summary.

\begin{tabular}{lllll}
\hline Model & $\mathbf{R}$ & $\begin{array}{l}\mathbf{R} \\
\text { Square }\end{array}$ & $\begin{array}{l}\text { Adjusted R } \\
\text { Square }\end{array}$ & $\begin{array}{l}\text { Std. Error of the } \\
\text { Estimate }\end{array}$ \\
\hline 1 & $.368^{\mathrm{a}}$ & .135 & .065 & .57417 \\
\hline
\end{tabular}

a. Predictors: (Constant), Agency Banking, Bancassurance, Electronic Money Transfer 
Table 4 outlines the results of coefficient of determination $\left(\mathrm{r}^{2}\right)$ and correlation coefficient $(\mathrm{R})$. The results of $\left(\mathrm{r}^{2}=0.135\right)$ and $(\mathrm{R}=0.368)$ reflected a positive weak correlation between the diversification strategies and competitive performance

Table 5. ANOVA.

\begin{tabular}{llllll}
\hline Model & Sum of Squares & df & Mean Square & F & Sig. \\
\hline Regression & 1.908 & 3 & .636 & 1.929 & $.142^{\mathrm{b}}$ \\
Residual & 12.198 & 37 & .330 & & \\
Total & 14.106 & 40 & & & \\
\hline
\end{tabular}

a. Dependent Variable: Competitive Performance

b. Predictors: (Constant), Agency Banking, Bancassurance, Electronic

Money Transfer

Table 5 presents the findings of analysis of variance (ANOVA). The analysis indicated that the diversification strategies had no significant effect on competitive performance at Equity bank $(\mathrm{F}=1.929 ; \mathrm{p}>0.05$ at $95 \%$ degree of confidence. These findings were based on the use of diversification strategies for the bank to enhance its competitive performance.

Table 6. Results of Regression Analysis.

\begin{tabular}{|c|c|c|c|c|c|}
\hline \multicolumn{6}{|l|}{ Coefficients $^{a}$} \\
\hline \multirow{2}{*}{ Model } & \multicolumn{2}{|c|}{$\begin{array}{l}\text { Unstandardized } \\
\text { Coefficients }\end{array}$} & \multirow{2}{*}{$\begin{array}{l}\begin{array}{l}\text { Standardized } \\
\text { Coefficients }\end{array} \\
\text { Beta }\end{array}$} & \multirow[b]{2}{*}{$\mathbf{t}$} & \multirow{2}{*}{ Sig. } \\
\hline & B & $\begin{array}{l}\text { Std. } \\
\text { Error }\end{array}$ & & & \\
\hline (Constant) & 3.082 & .766 & & 4.022 & .000 \\
\hline Bancassurance & .530 & .138 & .503 & 3.842 & .000 \\
\hline $\begin{array}{l}\text { Electronic Money } \\
\text { Transfer }\end{array}$ & -.613 & .169 & -.479 & -3.620 & .001 \\
\hline AgencyBanking & .293 & .119 & .320 & 2.470 & .008 \\
\hline
\end{tabular}

a. Dependent Variable: Competitive Performance

The outcomes of the regression analysis (Table 6) were interpreted using the following regression function: $\mathrm{Y}=\mathrm{a}+$ $\beta_{1} C_{1}+\beta_{2} C_{2}+\beta_{3} C_{3}+e$ where $\mathrm{Y}, C_{1}, C_{2}$, and $C_{3}$ represented bancassurance, electronic money transfers, and agency banking respectively. The results were interpreted as follows: $\mathrm{Y}=3.082+0.530 \mathrm{C}_{1}-0.613 \mathrm{C}_{2}+0.293 \mathrm{C}_{3}$. The results of the study implied that the first null hypothesis was rejected $(\mathrm{t}=3.842 ; \mathrm{p}<0.01)$. The findings further indicated that the second null hypothesis was rejected $(\mathrm{t}=-3.620 ; \mathrm{p}<0.01)$. Besides, the third null hypothesis was also rejected $(\mathrm{t}=2.470$; $\mathrm{p}<0.01$ ). The study findings further indicated that the competitive performance of equity bank was significantly influenced by 0.530 bancassurance, -0.613 electronic money transfers, 0.293 agency banking. Also, the results of the study indicated that the diversification strategies jointly influenced the competitive performance of Equity Bank $(\mathrm{t}=4.022$; $\mathrm{p}<$ $0.01)$.

\section{Conclusion and Recommendations}

\subsection{Conclusions}

The conclusions made in this section were in context of the objectives of the study. The study findings show that the relationship between bancassurance and competitive performance was positive, weak and not statistically significant. The weak correlation implied that the diversification based on bancassurance has some influence on the competitive performance of the bank. This was based on the customer perception about the bank based on benefits they perceive of the insurance products that are blended with banking products. The study observed that the bank operated as an insurance agent, it did not realize the full potential from the sale of insurance products as part of their revenues were shared with the principal insurers. The study also revealed a negative relationship between Electronic Money Transfer and competitive performance. The study observed that the electronic money transfers do not solely influence the performance of the bank as the banks profitability in not only dependent upon the charges for money transfers. However, it was observed that the electronic money transfers were convenient for completion of transactions and thus facilitated 24-hour banking operations even when the banking halls were closed over weekends. However, some users of the electronic money transfer systems did perceive the electronic funds transfer systems to be risky hence they expressed discontent with the systems for fear of loss. The study further indicated that the relationship between agency banking and competitive performance was negative, statistically insignificant $(\mathrm{r}=-0.154 ; \mathrm{p}>0.01)$. This implied that the adoption of agency banking does not solely influence competitive performance but together with a host of other diversification strategies, it influenced the bank's performance. Moreover, the study findings indicated that the agency banking system does not impact the performance of the bank.

\subsection{Recommendations}

The recommendations made in this study were based on the study findings in relation to the existing literature. According to the findings presented in the previous chapter, the following recommendations were imperative: first, there is need to develop bancassurance products that meet or seek to address the present and foreseeable needs of the customers It was also recommended that the bank should address the security-related fears expressed by a section of the respondents. It is also recommended that the organization should invest more in developing the capacities of its workforce and in particular provide incentives to motivate the employees to further their studies in information systems as a means of leveraging its competitive performance. It is further recommended that the bank should consider innovating its electronic money transfer systems to make the money transfer process simpler and easy to understand so as to enhance inclusivity of as many potential and existing customers as possible. The bank should also conduct elaborate advertisement campaigns to popularize agency banking as well as train their agents on exceptional service delivery. Trainings should also be done for the customers to increase their trust levels and improve their confidence in the agents. 


\subsection{Suggestions for Further Studies}

This study provided relevant insight on the adoption of diversification strategies on competitive performance of Equity bank. This study only focused on bancassurance, agency banking and electronic money transfer. It is important that further research is carried out to assess implications of the diversification strategies on the competitive performance of the product portfolio of the bank. The researcher suggests that similar studies be conducted in other commercial banks that provide similar products. Also, challenges affecting the growth of agency banking should also be researched on extensively to identify the reasons for its poor performance.

\section{References}

[1] Ansoff, H. I., (2003). A Model for Diversification. Burbank, Lockheed Aircraft Corporation.

[2] Arora, A. \& Jain, M., (2013). An Analysis on Contribution of Bancassurance on Financial Performance of Bank of India, Journal of Economics and Sustainable Development, Vol. 4(6) pp. 67-79.

[3] Chen, D., \& Stroup, W., (1993) General System Theory: Toward a Conceptual Framework for Science and Technology Education for All, Journal of Science Education andTechnology, 2(7).

[4] Chuttur, M. (2009). Overview of the Technology Acceptance Model: Origins, Developments and Future Directions. Sprouts: Working Papers on Information Systems, 9-37.

[5] Davis, F. (1989). Perceived Usefulness, Perceived Ease of Use, and User Acceptance of Information Technology. MIS Quarterly, vol. 13(3), pp. 319-340.

[6] Deonanan, A., (2011). Gordon Institute of Business Science. Diversification as a corporate strategy: an assessment of financial performance of industrial companies in South Africa.

[7] Equity Bank Limited, (2015). Equity Bank Kenya. Retrieved on $1^{\text {st }}$ August 14, 2015 from: http://www.equitybank.co.ke/about/our-history.

[8] Fauzi, H., Svensson, G., \& Rahman, A. A., (2010) Triple Bottom Line as Sustainable Corporate Performance: A Proposition for the Future. Sustainability, 2, 1345-1360.

[9] Issahaku, H., (2012), Challenges of Electronic Payment Systems in Ghana: The Case of e-ZWICH, American Journal of Business and Management, 1(3), 87-95.

[10] Mele, C., Pels, J., \& Polese, F., (2010) A Brief Review of Systems Theories and Their Managerial Applications. Service Science 2(1-2).

[11] Mukherji, A., (1998) The relationship between prior performance and diversification: a study of three industries. Management Decision, 36(3), 180-188.

[12] Musau, S. M. (2010). An Analysis of the Utilization of Agency Banking on Performance of Selected Banks in Nairobi County, Kenya. Kenyatta University. Unpublished Research Project.

[13] Ogare, H. O. (2013). The Effect of Electronic Banking on The Financial Performance of Commercial Banks in Kenya. University of Nairobi. P. 5-7.

[14] Oyewobi, L. O., Windapo, A. O., Cattell, K. S., (2013) Impact of business diversification on South African construction companies' corporate performance. Journal of Financial Management of Property and Construction, 18(2), 110-127.

[15] Peng, J. L., Jeng, V., Wang, J. L., Cheng, Y. C., (2015).The Impact of Bancassurance on Efficiency and Profitability of Banks:Evidence from the Banking Industry in Taiwan. Department of Risk Management and Insurance at the National Chengchi University, Taiwan.

[16] PWC, (2015) Price Waterhouse Coopers.

[17] Simon, S. M., Victor T. F., (1994), Customers Risk Perceptions of Electronic Payment Systems, International Journal of Bank Marketing, 12 (8), 26-38.

[18] Sorina, O. (2012). Banccasurance Development in Europe. International journal of Advances in Management and Economics, 6(01), 64-69.

[19] Steven, A. (2002). Information System: The Information of EBusines, New Jersey: Natalie Anderson. pp. 11-36.

[20] Teimet, P. R., Ochieng, D. O., \& Aywa, S., (2011) Income Source Diversification and Financial Performance of Commercial Banks in Kenya. International Journal of Business and Public Management, 1(1), 26-35.

[21] Teoh, W. M., Chong, S. C., Lin, B., \& Chua, J. W., (2013), Factors affecting consumers' perception of electronic payment: an empirical analysis, Internet Research, 23(4), 465- 485.

[22] Waweru, N. M., \& Kalani, V. M., (2009), Commercial Banking Crises in Kenya: Causes and Remedy, Global Journal of Finance and Banking Issues, 3(3). Weiers, R. M., (2011) Introductory Business Statistics. South-Western: Cengage Learning.

[23] Waweru, T. N., (2013). The effect of bancassurance on the financial performance of commercial banks in Kenya. Unpublished MBA project, University of Nairobi.

[24] Weiers, R. M., (2011) Introductory Business Statistics. SouthWestern: Cengage Learning.

[25] Zahra, S. A., \& Pearce, J. A. (1989). Boards of Directors and Corporate Financial Performance: A Review and Integrative Model. Journal of Management, 3(2). 